\title{
Effects of Sagebrush Control Methods and Seeding on Runoff and Erosion
}

\author{
JOHN C. BROWN, RAYMOND A. EVANS, AND JAMES A. YOUNG
}

\begin{abstract}
A large-plot (27 $\left.\mathrm{m}^{2}\right)$ rainfall simulator was used to examine the effects of controlling Wyoming big sagebrush (Artemisia tridentata ssp. wyomingensis) and seeding with crested whestgrass (A gropyron desertorum) upon infiltration rates and soil erosion in central Nevada. A new parameter-runoff initiation frequency index (an estimate of frequency of occurrence in years that a natural storm will produce surface runoff at the site) was also used for making treatment comparisons. The runoff initiation index reflects a more comprehensive appraisal of hydrologic response on semiarid rangelands than does infiltration rate but sometimes results in a different assessment of treatment effects. Initially, all range improvement techniques reduced terminal infiltration rates and increased sediment yields. The magnitude of treatment effects varied in proportion to the degree of site disturbance: plowing/seeding caused the greatest impact, burning/seeding next, and spraying/seeding had only minimal effect. Treatments showed a steady trend toward recovery in a 2-year period. In terms of runoff initiation frequency, however, plowing/seeding had the least detrimental effect with burning/seeding and spraying/seeding having greater effect. Trends subsequent to treatment indicated watershed improvement of plowed/seeded areas and a decline in burned/seeded areas. These somewhat contradictory results are due to the runoff retention capability of furrows created by plowing and/or artificially seeding across the slope. Surface storage characteristics are incorporated in runoff initiation frequency indexing but not in infiltration rates alone.
\end{abstract}

The history of brush control and seeding for improvement of big sagebrush (Artemisia tridentata)/grassland communities dates to the early 1930's. Since that time, millions of hectares of depleted sagebrush rangelands have been cleared and seeded to crested wheatgrass (Agropyron cristatum and A. desertorum)(See Young and Evans 1984 for history of crested wheatgrass). Associated research efforts have focused on development of better brush control and seeding techniques and evaluation of livestock response, vegetative changes, and success of seeding under varying conditions of site and climate. Little attention has been given to hydrologic implications of sagebrush rangeland improvement.

Traditionally, it was assumed that replacing brush with perennial grasses automatically improves watershed condition regardless of methods used or site characteristics. Research findings, though scanty, do not always support this concept of automatic improvement. Blackburn (1983) provides a summary of previous studies of the effects of sagebrush rangeland improvement techniques on infiltration rates and sediment yield.

The authors are, respectively, former research assistant in hydrology, University of Nevada, deceased, and range scientists, USDA. Agr. Res. Serv., 920 Valley Road. Reno.

This manuscript is submitted with the approval of the Director, Nevada Agricultura! Experiment Station, as Journal Series No. 575

Manuscript accepted July 3, 1984.
Disk plowing for brush control followed by artificial seeding has received the most attention. Studies in the East Gate Basin of Nevada in the late 1960 's report that this treatment initially reduced infiltration rates and increased sediment yields with lingering effects detectable after 3 years (Gifford and Skau 1967, Gifford 1968, Jager 1972). In other areas of Nevada, Blackburn and Skau (1974) reported no significant differences in infiltration rates and sediment yields between untreated areas and areas disk plowed and seeded 5 and 6 years previously. Another site in Nevada that had been railed and artificially seeded was tested 17 years following treatment. Here infiltration capacity was increased and sediment yield reduced when compared to untreated areas (Blackburn and Skau 1974). In southern ldaho, Gifford (1982) reports similar initial results from disk plowing and artificial seeding. Here tests in succeeding years revealed a 4-6 year trend toward recovery. On a watershed scale, sediment yields were apparently reduced following plowing, seeding, and successful establishment of beardless bluebunch wheatgrass (Agropyron inerme) in Colorado (Lusby 1979).

Spraying with herbicide $(2,4-D)$ for sagebrush control and seeding crested wheatgrass into standing dead brush with a rangeland drill is another popular improvement technique. In the East Gate basin studies (Gifford and Skau 1967, Gifford 1968, Jager 1972) spraying and seeding had little effect on infiltration rates and soil loss, apparently due to the minimal soil disturbance caused by the treatment. Similar results have generally been reported for herbicide treatments in other areas (Balliette and McDaniel 1983) and other vegetation types such as chaparral and honey mesquite (Prosopis glandulosa var. glandulosa).

The use of fire for sagebrush control is gaining popularity. Hydrologic effects of burning sagebrush rangelands have not been investigated (Blackburn 1984). Burning in other brush types has had mixed results: in chaparral sites of the Southwest, burning greatly increased sediment yields and reduced infiltration rates due to the buildup of a water repellent soil layer after the fire (Glendening et al. 1961, Rowe et al. 1954, Rice 1973). In pinyon (Pinus spp.) and juniper (Juniperus spp.) woodlands burning significantly increased erosion and runoff on moderate and steep slopes (Wright et al. 1976) and had lesser effects on gentle slopes (Roundy et al. 1974). On running mesquite (Prosopis reptans) sites in south Texas, burning apparently had little effect on infiltration rates and soil loss (Knight et al. 1983).

This study was designed to investigate, on an arid Wyoming big sagebrush site, the initial effects on infiltration rates, surface run off and soil erosion of disk plowing, herbicide application, and burning for brush control and the subsequent changes within 2 years after treatment in hydrologic condition following seeding of crested wheatgrass

\section{Study Area and Methods}

\section{Study Area}

Brush control and seeding treatments were applied to degraded sagebrush rangelands on alluvial fan areas of the University of 
Nevada's Gund Research and Demonstration Ranch in Grass Valley, Nevada. Wyoming big sagebrush is the dominant brush species with a sparse understory of sandberg bluegrass (Poa secunda), squirreltail (Sitanion hystrix), Indian ricegrass (Oryzopsis hymenoides), and cheatgrass (Bromus tectorum). Thurber's needlegrass (Stipa thurburiana) and bluebunch wheatgrass (Agropyron spicatum) may have once occurred on the fans (Young and Evans 1980) but a history of heavy livestock use has greatly reduced the diversity of native perennial grasses and increased the dominance of cheatgrass.

Soils of the alluvial fans are complex due to the action of Pleistocene Lake Gilbert, which formed a series of offshore bars and lagoons as it receded during the Holocene period. Brush control and seeding were done on soils of 2 series identified on the fan areas. One is an Abgese loam belonging to the xeroliic haplargid family. The other is a McConnel gravelly sandy loam within the xerollic camborthid family. Though taxonomically separate, the surface properties of the 2 series were very similar, consisting of loam soil with slight, very fine, vesicular pore development and $30-50 \%$ coverage by small rock in interspace areas. Coppice dunes found under shrub canopies averaged $54 \%$ cover for Abgese soils and $51 \%$ for McConnel soils (Cluff et al. 1984). Landform slopes of the treated area averaged $4-10 \%$ with a westerly aspect.

Mean annual precipitation ranges from 200 to $360 \mathrm{~mm}$ with most falling in low intensity storms during the winter and early spring. Summer thunderstorms bring high intensity rainfall 15 to 20 days a year in the summer and early fall (Houghton et al. 1975).

\section{Brush Control and Seeding Treatments}

In the spring and summer of 1979 , twelve rectangular exclosures approximately 16 ha in size were established in the area to exclude cattle grazing for the duration of the study. Various range improvement treatments were established in the exclosures including brush control by disk plowing, by application of $2,4-\mathrm{D}$, and by pescribed burning, each followed by seeding of crested wheatgrass (cultivar, Nordan). Disk plowing was accomplished during the summer of 1979 in 2 directions using a brushland plow with the second-direction plowing making furrows on the contour across the slope. This treatment thoroughly mixed soil, including shrub coppice and interspace areas, to a depth of about $25 \mathrm{~cm}$. Spraying was done in early May 1979 and 1982 on different plots with a modified ground sprayer (Young et al. 1979) that applied 3.3 $\mathrm{kg}$./ ha a.e. of 2,4-D low volatile ester in water at $1051 /$ ha. Ground disturbance resulting from this treatment was minimal. Crested wheatgrass was seeded to treated areas at a rate of $9 \mathrm{~kg} / \mathrm{ha}$ in
October 1979 using a standard rangeland drill. The drill produces furrows $30 \mathrm{~cm}$ apart and about $5 \mathrm{~cm}$ deep. Drilling was done on the contour across the slope. Prescribed burning for brush control was accomplished in August 1980. The fire was hot enough to consume virtually all plant litter and standing vegetation. Part of the burned area was seeded to crested wheatgrass using the standard rangeland drill in October 1980. Another part of the burn was left unseeded. Cluff et al. (1984) and Evans and Young (1980) give more detailed descriptions of treatments and study area characteristics.

\section{Watershed Methods}

The rainfall simulator selected for use at the Gund Ranch is of a basic design reported by Holland (1969), modified by Lusby and Toy (1976), and further modified by members of the Bureau of Land Management, Denver Service Center and study personnel (Fig. 1). It consists of 7 sprinkler heads mounted on 3 meter risers

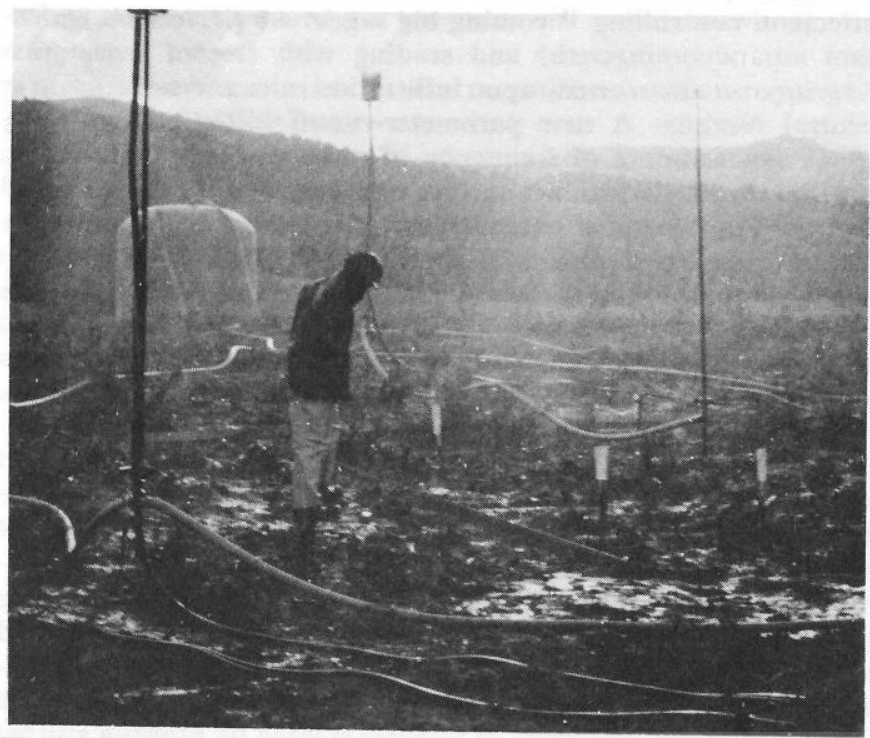

Fig. 1. Rainfall simulator sprinkling water on a plowed and seeded plot.

spaced in an hexagonal pattern, 1 head at each corner of the hexagon and 1 in the middle; corner heads are all $6.1 \mathrm{~m}$ from the middle head and corners are each $6.1 \mathrm{~m}$ from one another. This design and a constant water pressure of $2 \mathrm{~kg} / \mathrm{cm}^{2}$ produce a theoretically uniform rainfall intensity of $5 \mathrm{~cm} / \mathrm{hr}$ over a $27 \mathrm{~m}^{2}$ plot $(5.5$

Table 1. Hydrologic parameters in relation to range improvement treatments at the Gund Ranch Nevada. ${ }^{1}$

\begin{tabular}{|c|c|c|c|c|c|}
\hline \multirow{2}{*}{$\begin{array}{l}\text { Soil Series } \\
\text { Treatment }^{2} \\
\end{array}$} & \multicolumn{2}{|c|}{$\begin{array}{c}\text { Terminal Infiltration } \\
\text { Rate }(\mathrm{cm} / \mathrm{hr}) \\
\end{array}$} & \multicolumn{2}{|c|}{$\begin{array}{c}\text { Runoff Return } \\
\text { Frequency (Year) } \\
\end{array}$} & \multirow{2}{*}{ 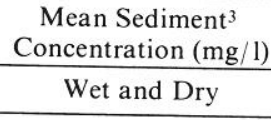 } \\
\hline & Dry Runs & Wet Runs & Dry Runs & Wet Runs & \\
\hline \multicolumn{6}{|l|}{$\begin{array}{l}\text { McConnel Soil Series } \\
\text { Check }\end{array}$} \\
\hline Check $(1980,81,82)$ & $4.14^{\mathrm{a}}$ & $3.51^{\mathrm{a}}$ & $17.0^{\mathrm{b}}$ & $7.3^{\mathrm{ab}}$ & $800^{\mathrm{e}}$ \\
\hline Plow + Seed - 1979 (1979) & $3.40^{\mathrm{ab}}$ & $0.66^{\mathrm{cd}}$ & $34.0^{\mathrm{a}}$ & $4.8^{\mathrm{bc}}$ & $10330^{\mathrm{a}}$ \\
\hline Plow + Seed - $1979(1980)$ & $4.04^{a}$ & $1.70^{\mathrm{bc}}$ & $17.0^{\mathrm{b}}$ & $6.2^{\mathrm{abc}}$ & $2802^{\mathrm{bc}}$ \\
\hline Plow + Seed - $1979(1981)$ & $4.39^{2}$ & $2.18^{\mathrm{b}}$ & $46.0^{\mathrm{a}}$ & $8.8^{\mathrm{a}}$ & $1398^{\text {de }}$ \\
\hline Spray + Seed - $1982(1982)$ & $4.17^{\mathrm{a}}$ & $1.78^{\mathrm{bc}}$ & $19.0^{\mathrm{b}}$ & $4.2^{\mathrm{bc}}$ & $1581^{\text {cde }}$ \\
\hline \multicolumn{6}{|l|}{ Abgese Soil Series } \\
\hline Check $(1980,81)$ & $4.34^{\mathrm{a}}$ & $3.66^{\mathrm{a}}$ & $18.0^{\mathrm{b}}$ & $6.3^{\mathrm{abc}}$ & $1571^{\text {cde }}$ \\
\hline Burn - $1980(1980)$ & $3.15^{\mathrm{ab}}$ & $1.98^{\mathrm{b}}$ & $6.8^{\mathrm{b}}$ & $3.7^{\mathrm{bc}}$ & $3325^{\mathrm{b}}$ \\
\hline Burn - $1980(1982)$ & $2.49^{\mathrm{b}}$ & $1.07^{\text {bcd }}$ & $4.5^{b}$ & $3.7^{\mathrm{bc}}$ & $1793^{\text {cde }}$ \\
\hline Burn + Seed - $1980(1980)$ & $2.03 \mathrm{~b}$ & $0.36^{\mathrm{d}}$ & $18.0^{\mathrm{b}}$ & $4.3^{b c}$ & $3330^{\mathrm{b}}$ \\
\hline Burn + Seed - $1980(1981)$ & $3.10^{\mathrm{ab}}$ & $0.53^{\mathrm{cd}}$ & $18.0^{\mathrm{b}}$ & $4.2^{\mathrm{bc}}$ & $2276^{\text {bcd }}$ \\
\hline Burn + Seed - $1980(1982)$ & $3.30^{\mathrm{ab}}$ & $1.22^{\mathrm{bcd}}$ & $10.0^{\mathrm{b}}$ & $3.4^{\mathrm{c}}$ & $3023^{\mathrm{b}}$ \\
\hline \multirow{2}{*}{$\begin{array}{l}\text { Burn, Seed, Reseed - } 1982 \\
\quad(1982)\end{array}$} & $262^{\mathrm{b}}$ & & $5.2^{b}$ & $3.7^{\mathrm{bc}}$ & $1005^{\mathrm{de}}$ \\
\hline & & $0.58^{\mathrm{cd}}$ & & & $1005^{\circ}$ \\
\hline
\end{tabular}

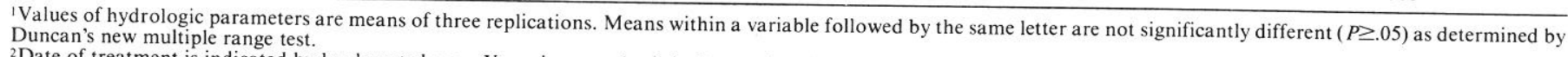

${ }^{2}$ Date of treatment is indicated by hyphenated year. Years in parenthesis indicate when data from simulator runs were collected.

No significant differences in sediment yield were observed between wet and dry runs so combined yields are presented. 
$\times 4.9 \mathrm{~m}$ ). Drop size varied from 1.75 to $2 \mathrm{~mm}$ vs. $2.7 \mathrm{~mm}$ for natural rainfall. Kinetic energy of simulated rainfall was $54 \%$ that of natural rainfall (Lewis and Parsons 1943). Rainfall intensity of 5 $\mathrm{cm} / \mathrm{hr}$ was found to be necessary to ensure runoff from all treatments. Applied rainfall was measured with a network of rain gauges to check on amount and uniformity of application with respect to time intervals within a run and to location within the $27-\mathrm{m}^{2}$ plot. Plot borders of sheet metal were carefully installed around the top 3 sides and a collection ditch and flume were placed along the downhill side of the plot. The collection ditch was stabilized with an adhesive coating. Rainfall was applied to each plot, first with the soil initially dry (dry run) and again 24 hours later with the soil at field capacity (wet run). Each application varied from 30 minutes to 1 hour, depending on the uniformity of the observed terminal infiltration rate. During each run, runoff volume and sediment concentration were determined at approximately 1.5-minute intervals. Infiltration rate for each runoff measurement was calculated as the difference between application rate $(\mathrm{cm} / \mathrm{hr})$ and runoff rate $(\mathrm{cm} / \mathrm{hr})$, and an infiltration curve was plotted for each run. Sediment concentrations represent total-load sediment and were determined gravimetrically in the laboratory. Four major infiltration characteristics and one of erosion were obtained for each run. These include: (1) time of ponding and (2) time of runoff; both subjectively determined during the run; (3) time to peak of the runoff hydrograph; (4) terminal infiltration rate, determined from the infiltration curve; and (5) mean sediment concentration, an arithmetic average of samples collected during rainfall application.

The effects of disk plowing and seeding were tested with the simulator on the McConnel soil series. Three plots, with a wet and dry run on each, were run 2 weeks following treatment in the fall of 1979. Three plots were again run in the summers of 1980 and 1981 . Three check (untreated) plots on degraded range with soil of the McConnel series were run in the summer of 1980, 4 in 1981, and 2 in 1982. The spray and seed treatment was also tested on 3 plots on the McConnel series in the summer of 1982, in an area sprayed in May 1982 and seeded about 2 weeks before the simulator runs. Tests involving prescribed burning were run on the Abgese soil series. Three plots were run in the area before the burn in the summer of 1980 (check plots). Three plots were run immediately after burning and 3 more were run after seeding in the fall of 1980 . Three check (unburned native range) plots were also run in the fall of 1981 , as well as 3 plots in the burned and seeded area. In the summer of 1982, 3 plots were run in the burned and seeded area, 3 were run in an area burned and seeded in 1980 and reseeded in 1981 , and 3 more were run in an area burned in 1980 and never seeded. Individual plots were selected on a random basis among sites that characterized surface soil features of the site and soil that were represented.

Three dependent variables were used to evaluate the effects of treatment on infiltration and soil erosion. These included sediment yield, terminal infiltration rate, and runoff initiation frequency. Sediment yield is expressed as the mean sediment concentration ( $\mathrm{mg} / \mathrm{l}$ ) of runoff water collected during the simulator run. Terminal infiltration rate $(\mathrm{cm} / \mathrm{hr})$ is taken from the infiltration curve for each wet and dry run at the low point or where the curve becomes flat. Runoff initiation frequency is an index estimating the frequency of occurrence in years that a natural storm will produce surface runoff at the site.

The first 2 variables are commonly used in infiltration studies and provide estimates of infiltration capacity of soil and soil erosion rates if infiltration capacity is exceeded. Since generalized surface runoff occurs infrequently on most native rangelands, a comprehensive perspective of erosion hazard requires a frequency term to estimate how often runoff will occur. An index was developed to relate local intensity-duration characteristics of precipitation with existing hydrologic response of a site, including initial infiltration characteristics. To compute runoff initiation frequency for each simulator run, a working diagram (Fig. 2) was produced

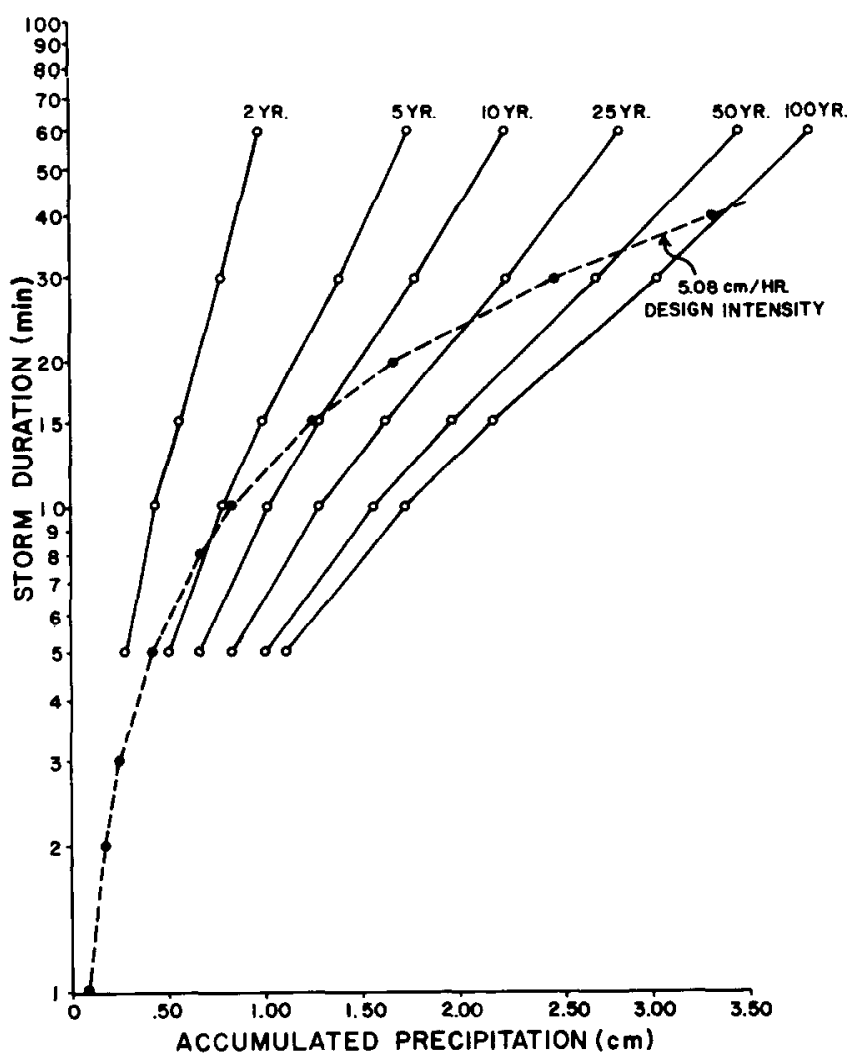

Fig. 2. Precipitation intensity-duration characteristics for the Gund Ranch, central Nevada.

from data and procedures outlined by Miller et al. (1973). The diagram is a semi-log plot with the ordinate being the log of storm duration in minutes and the abscissa being accumulated precipitation $(\mathrm{cm})$. Storm return frequencies for various years are also shown on the figure. This chart graphically represents the intensityduration characteristics of storms for central Nevada: high intensities are of short duration; average intensity is reduced as period of precipitation increases. The dashed line indicates how the "storm" produced by the rainfall simulator compares to natural rainfall in terms of intensity and duration. Rainfall applied at $5 \mathrm{~cm} / \mathrm{hr}$ for 5 minutes simulates the maximum natural storm that is predicted to occur about every 4 years. After 40 minutes, however, the simulator was applying a 100-year storm.

To obtain runoff initiation frequency for a simulator run, time in minutes until runoff first occurred from the plot is located on the ordinate and carried horizontally across the chart until it intersects a vertical line representing accumulated precipitation depth since the start of the simulator run (or the dashed lines if the design intensity has been accurately maintained). When this intersection point is compared with the solid equal-frequency lines a return frequency can be estimated.

An index relating rainfall simulator data to local intensityduration characteristics of precipitation provides considerable information. Not only can an assessment be made of how often runoff from a site is likely to occur; estimates of runoff volume and soil loss for a design storm of a return frequency can be made. This is done using precipitation characteristics from Figure 2 and the infiltration curve produced from the rainfall simulator. For example, Figure 2 shows that a design storm of 25 -year frequency is produced after 24 minutes of simulated rainfall. If runoff occurs after 9 minutes, runoff initiation frequency for this site is about 5 ycars. Excess runoff will occur for 15 minutes with a 25 -year storm. If an average infiltration rate for this 15 minute period is $2 \mathrm{~cm} / \mathrm{hr}$, estimated from the infiltration curve, runoff rate will be application rate $(5 \mathrm{~cm} / \mathrm{hr})$ minus infiltration rate $(2 \mathrm{~cm} / \mathrm{hr})$ or $3 \mathrm{~cm} / \mathrm{hr}$. This rate and duration of 15 minutes yields $0.75 \mathrm{~cm}$ total runoff from the site. Sediment yield in $\mathrm{kg} /$ ha can be estimated by taking 
sediment concentration data for the 15-minute runoff excess period and combining them with total runoff and appropriate conversion factors.

Comparisons of treatment response for each variable were made bet ween treated and control areas and within a treatment in different years. One-way analysis of variance and Duncan's new multiple range test were used to assess the significance of mean differences at the .05 level of probability.

\section{Results and Discussion}

Antecedent soil moisture (wet vs. dry runs) was found to have significant ( $P \geq .05$ ) effect on terminal infiltration rate and runoff frequency; wet runs had lower infiltration and greater runoff frequency regardless of treatment (Table 1). No significant differences in sediment yield between wet and dry runs were observed. In all subsequent treatment comparisons, means for wet and dry runs were handled separately for infiltration rate and runoff frequency, but were combined for sediment yields.

No significant differences wcre found between means of any variable for check plots run in different years on the same soil series. Data from these were lumped to form one set for check plots on each soil series.

\section{Plowing and Seeding}

The effects of plowing and seeding on infiltration rates and sediment yields were similar to those found in previous infiltration studies: immediately after treatment there was an initial lowering of infiltration rate for both wet and dry runs (Table 1). Tests in succeding years showed steady recovery, but after 2 years the wet-run terminal rate was still significantly lower than that for the check. Sediment yield also exhibited this pattern. Treatment initially caused a ten-fold increase in soil loss rate. After 2 years, however, soil losses on treated plots decreased so they were not significantly different than those for check plots. The runoff initiation frequency index reflected somewhat different results. Initially, plowing and seeding significantly reduced runoff initiation frequency under dry soil conditions. Even after 2 years, runoff on these plots was significantly less than on check plots. With the soil initially wet, results more similar to those for terminal infiltration rate were seen. The treatment produced an initial increase in runoff frequency but a steady trend toward recovery was shown. The discrepancy between treatment effects on infiltration rate and those on runoff initiation frequency can be attributed to surface storage water behind furrows created by plowing and seeding across the slope. The furrows retarded runoff, causing a lower erosion hazard from this treatment than what might be inferred from infiltration rates alone.

\section{Spraying and Seeding}

The effects of spraying and seeding were similar to plowing and seeding but of considerably lesser magnitude (Table 1). For dry runs, no differences in infiltration rates, a minor reduction in runoff initiation frequency, and some increase in sediment yield were observed on sprayed and seeded plots compared to check plots. Terminal infiltration rate was significantly reduced and runoff initiation frequency increased for wet runs on the treated plots compared to check plots. Apparently, results again reflected the effects of land disturbance caused by mechanical seeding. Although disturbance was minor compared to plowing, the increase in surface storage from the rangeland drill furrows caused a less detrimental effect on runoff initiation frequency than on infiltration rate.

\section{Prescribed Burning and Seeding}

Treatments involving burning showed different results than did plowing or spraying (Table 1). Simulated rainfall applied soon after burning exhibited almost immediate ponding on burned coppice dunes. This was apparently caused by water repellency of burned organic matter. No runoff was observed from dune areas, however, indicating that the repellency was not strong or persistent. Interspace areas seemed to respond normally or not differently from untreated areas. Burning lowered infiltration rates significantly for wet runs ( $P \geq 05$ ), increased runoff initiation frequency, and doubled sediment concentrations. Seeding the burned area produced an even more dramatic reduction in infiltration. Runoff initiation frequency, on the other hand, was sizeably reduced, again due to surface storage in drill furrows. Here sediment yields were unaffected by seeding.

Tcsts in years following burning and seeding indicated a steady recovery in infiltration and a steady decline in runoff initiation frequency. Recovery in infiltration rate was due to the gradual establishment of crested wheatgrass; the decline in runoff initiation frequency to the smoothing of furrows and reduction of surface storage. Sediment yields were similar from 1980 to 1982 subsequent to seeding. Part of the burned and seeded area was reseeded in the spring of 1982. Infiltration capacity was substantially reduced for both wet and dry runs, essentially nullifying most recovery that had taken place since 1980 . Runoff initiation frequency was increased for dry runs and slightly reduced for wet runs. Sediment yields were reduced following reseeding.

An area burned in 1980 and never seeded was tested in 1982. This area showed a decline in infiltration capacity for both wet and dry runs. Runoff initiation frequency was increased for dry soil and stayed the same for wet runs. Sediment yields were Iower than those measured immediately after burning.

\section{Summary and Conclusions}

The response of sagebrush rangelands disk plowed and seeded to crested wheatgrass was similar, in terms of infiltration and sediment yield, to that reported in previous studies. The same is generally true for rangelands where sagebrush was sprayed with 2,4-D and seeded. Mechanical land disturbance, even the minor effects of the rangeland drill, has an initial negative impact on infiltration rates. Where mechanical disturbances creates storage and retention of ponded water, runoff from the site is retarded. In terms of runoff initiation frequency, then, both treatments actually improved hydrologic conditions with initially dry soil, and had a much lower negative impact with the soil initially wet than would be inferred from infiltration rate measurements. Trends show steady improvement in all study parameters in years following disk plowing and seeding.

Burning had an initial negative impact on infiltration rate and increased sediment transport. After 2 years, areas burned and not seeded exhibited a further decline in hydrologic condition, except for a lowering in sediment yields. This decline can probably be attributed to the buildup of a water repellent layer, mainly on old coppice dune areas, and the poor regrowth of vegetation in areas not seeded. Seedıng the burned area caused an initial lowering in infiltration rates and a decrease in runoff initiation frequency. The increase in surface storage from drill furrows outweighed the negative impacts of mechanical disturbance on infiltration, causing a net lowering of runoff hazard. Trends monitored for 2 years, however, show a steady improvement in infiltration capacity and a steady increase in runoff initiation frequency. Improvement in infiltration capacity can be attributed to increases in plant cover from the seeding; increases in runoff initiation frequency may be caused by filling in of furrows and a reduction of surface water storage capacity on the site.

In this study, evaluations of treatment effects have been made using 2 indicators: terminal infiltration rate and a runoff initiation frequency index. Obscrved results were often different and sometimes conflicting between the 2 values. The reason is that runoff initiation frequency is dependent upon initial soil infiltration characteristics, whereas, infiltration rates reported here are terminal rates which generally occur long after runoff has started. Additionally, runoff initiation frequency incorporates local precipitation patterns and storage capabilities of the soil surface. Thus, 
the 2 values reflect 2 different hydrologic characteristics. Runoff initiation frequency is an estimate of how often surface runoff may occur while terminal infiltration rates provide an estimate of volume of runoff if rainfall is known. In areas where natural runoff occurs very rarcly, runoff initiation frequency may be a more important indicator than runoff volume. Where natural runoff occurs often, runoff volume may be a more important measure of erosion hazard.

\section{Literature Cited}

Balliette, J.F., and K.C. MeDaniel. 1984. Monitoring range improvement following chemical control of sagebrush. Abs. Soc. Range Manage. No. 224.

Blackburn, W.H. 1983. Influence of brush control on hyd rologic characteristics of range watersheds. Proc. Brush Manage. Symposium, Soc. for Range Manage. Albuquerque, N. Mex. Feb. 16, 1983. Texas Tech. Univ. Press. p. 73-88.

Blackburn, W.H., and C.M. Skau. 1974. Infiltration rates and sediment production of selected plant communities in Nevada. J. Range Manage. 27:476-480

Cluff, G.J., J.A. Young, and R.A. Evans. 1983. Edaphic factors influencing the control of Wyoming big sagebrush and seeding establishment of crested wheatgrass. J. Range Manage. 36:786-792.

Gifford, G.F. 1982. A long-term infiltrometer study in southern Idaho. J. Hydrol. 58:367-374.

Gifford, G.F. 1968. Influence of various rangeland cultural treatments on runoff, sediment production and soil moisture patterns in the big sagebrush type East Gate Basin, Nevada. Ph. D. Diss. Utah State Univ., Logan.

Gifford, G.F., and C.M. Skau. 1967. Influence of various rangeland cultural treatments on runoff and sediment production from the big sagebrush type, East Gate Basin, Nevada. Proc. Third Amer. Water Resources Conf. p. 137-148.

Glendening, G.E., C.P. Pase, and P. Ingebo. 1961. Preliminary hydrologic effects of wildfire in chaparral. Proc. Ariz. Watershed Symp. 5:12-15.

Holland, M.E. 1969. Design and testing of rainfall system. Colorado State Exp. Sta. Ser. 69-70. MEH 21. Fort Collins.

Houghton, J.G., C.M. Sakamoto, and R.O. Gifford. 1975. Nevada's weather and climate. Nevada Bureau of Mines and Geology. Univ. of Nev., Reno. p. 141-160.
Jager, D.L. 1972. The influence of cultural practices and seeded species on overland flow and sediment production from the big sagebrush cover type in East Gate Basin. Ph.D. Diss., Univ. of Nevada, Reno.

Knight, R.W., W.H. Blackburn, and C.J. Scifres. 1983. Infiltration rates and sediment production following herbicide/fire brush treatments. J., Range Manage. 36:154-157.

Lewis, J.O., and D.A. Parsons. 1943. The relation of raindrop size to intensity. Trans. Amer. Geogr. Union 24:452-459.

Lusby, G.C. 1979. Effects of converting sagebrush cover to grass on the hydrology of small watersheds at Boco Mountain, Colo. U.S. Geol. Surv. Water Supply Paper 1532-J.

Lusby, G.C., and T.J. Joy. 1976. An evaluation of surface mine spoils area restoration in Wyoming using rainfall simulation. Earth Surface Processes, Vol. 1, 1976. p. 375-386.

Miller, J.F., R.H. Frederick, and R.J. Tracey. 1973. Precipitationfrequency at las of the western United States, Vol. VII-Nevada. U.S. Dep. Comm. NOAA Atlas 2. Nat. Weather Serv. Silver Springs, Md.

Rice, R.M. 1973. The hydrology of chaparral watersheds. p. 27-34. In: Proc. Symp. on Living with the Chaparral, Univ. of California, Riverside.

Roundy, B.A., W.H. Blackburn, and R.E. Eckert, Jr. 1978. Influence of prescribed burning on infiltration and sediment production in the pinyon/juniper woodland, Nevada. J. Range Manage. 31:250-253.

Rowe, P.B., C.M. Countryman, and H.C. Storey. 1954. Hydrologic analysis used to determine effects of fire on peak discharge and erosion rates in southern California watersheds. USDA, Forest Serv., Calif., Forest and Range Exp. Sta.

Wright, H.A, F.M. Churchill, and W.C. Stevens. 1976. Effect of prescribed burning on sediment, water yield, and water quality from dozed juniper lands in central Texas. J. Range Manage. 29:294-298.

Young, J.A., and R.A. Evans. 1984. History of crested wheatgrass in the Intermountain Area. Proc. Crested Wheatgrass Symposium, Utah State University (in press).

Young, J.A., and R.A. Evans. eds. 1980. Physical, biological, and cultural resources of the Gund Research and Demonstration Ranch, Nevada. USDA, Sci. and Ed. Adm., Agr. Rev. and Manuals. ARM-W-11.

Young, J.A., B.A. Roundy, A.D. Bruner, and R.A. Evans. 1979. Ground sprayer for sagebrush rangelands. USDA, Sci. and Ed. Adm., Adv. in Agr. Tech. AAT-W-8.

\section{Instructions for Authors}

Information for authors preparing manuscripts for the Journal of Range Management is contained in the Handbook of Style available from the Society for Range Management, 2760 West Fifth Avenue, Denver, Colorado 80204. Individual copies are $\$ 1.25$ postpaid; additional copies are $\$ 1.00$ each. 